\title{
Rights Based Refuge, the Potential of the 1951 Convention and the Need for Authoritative Interpretation
}

\section{TOM CLARK*}

\begin{abstract}
Non-refoulement is the central part of the protection of the 1951 Convention Relating to the Status of Refugees. It is true that Article 1, a definition, is the passport to Convention refugee status and the expectation of naturalization. However, this affects only a fraction of the world's refugees. Non-refoulement, and the form of protection it brings, affects 10-15 million refugees.

Although it is now recognized that non-refoulement has been reinforced by other human rights treaties, such as the Convention against Torture, $(\mathrm{CAT})$, the full impact has not been grasped. Non-discrimination obligations from Article 26 of the 1966 Covenant on Civil and Political Rights, (CCPR) can limit differentiations in the allocating of rights and benefits.

A review of rights based refuge is timely because the content, what is enjoyed beyond the refuge itself, is highly variable and relates, in part, to ambiguities in key terms allocating rights in the Convention. However, the refugees involved may be persons protected from expulsion not only by the Convention, but also by the newer human rights treaties. So the content problems also relate to a lack of interpretation of human rights treaties as these apply to persons protected from expulsion.

Throughout, this essay shows that authoritative interpretation of treaties is needed to make the promise of the rights based refuge a reality for refugees.
\end{abstract}

\section{Introduction}

There is a need to look again at non-refoulement. An opinion on the principle of non-refoulement was one topic among nine rather than the central theme of the 2001 Global Consultations of the UNHCR. ${ }^{1}$ The impact of human rights treaties on non-refoulement can only grow. It is time to begin to replace academic opinions with authoritative treaty interpretation.

Non-refoulement is the central part of the protection of the 1951 Convention Relating to the Status of Refugees. ${ }^{2}$ It is true that Article 1,

* Associate, Gentre for Refugee Studies, York University.

1 Elihu Lauterpacht and Daniel Bethlehem, 'The Scope and Content of the Principle of Non-Refoulement: Opinion', in Erika Feller, Volker Türk and Frances Nicholson (eds.), Refugee Protection in International Law, Cambridge: Cambridge University Press, 2003.

${ }^{2}$ Guy Goodwin-Gill, 'The Refugee in International Law', $2^{\text {nd }}$ Edition, Oxford: New York 1996, 389. Unless otherwise specified, references to the 1951 Gonvention will take for granted the concurrent application of the 1967 Protocol. 
a definition, is the passport to Convention refugee status and the expectation of naturalization. However, this affects only a fraction of the world's refugees. ${ }^{3}$ Non-refoulement, and the form of protection it brings, affects 10-15 million refugees. ${ }^{4}$ It deserves revisiting.

Although it is now recognized that non-refoulement has been reinforced by other human rights treaties, such as the Convention against Torture, (CAT), the full impact has not been grasped. Non-discrimination obligations from Article 26 of the 1969 Covenant on Civil and Political Rights, (CCPR) can limit differentiations in the allocating of rights and benefits. This article calls into question the differentiations originally provided in the text of the 1951 Convention. ${ }^{5}$ This is because treaties are to be interpreted in their current juridical context, which includes the body of subsequent rights and benefits and related jurisprudence. ${ }^{6}$ As a consequence, non-refoulement must now be viewed as part of a wider "rights based refuge". What is the significance and potential of rights based refuge as human rights treaties become increasingly important? Who is affected? How do they benefit? How might they benefit?

There are other reasons that make the examination of rights based refuge timely. Governments on the Standing Committee of the Executive Committee of the UN High Commissioner for Refugees' program have identified certain protection needs: 'temporary protection' in mass exoduses, ${ }^{7}$ and 'complementary protection' for individuals. ${ }^{8}$ The Standing Committee described these as matters for State discretion. Yet it can be argued that these persons may claim such protection as 'rights based protection'. The protection of persons in mass influxes and the role of temporary protection were raised during UNHCR's Global Consultations in 2001 , but without any significant advances. ${ }^{9}$

A review of rights based refuge is timely because the content, what is enjoyed beyond the refuge itself, is highly variable and relates, in part, to

31951 Gonvention, Art. 34 requires '... States shall as far as possible facilitate the assimilation and naturalization of refugees ...'.

${ }^{4}$ Unless stated otherwise 'refugees' means persons qualifying under the Mandate of UNHCR as extended by direction of the General Assembly, all as provided in the 1950 Statute of the UNHGR.

5 Tom Glark with Francois Grépeau, 'Mainstreaming Refugee Rights. The 1951 Refugee Convention and International Human Rights Law', 17 Netherlands Quarterly of Human Rights 389 (1999).

6 The Vienna Convention on the Law of Treaties is the standard for treaty interpretation. Article 31 requires using the ordinary meaning of the text in context of the whole treaty and using the juridical context of subsequent agreements such as human rights treaties. See Clark with Crépeau (1999), above n. 5 at 391 and 393.

7 Standing Committee, Progress Report on Informal Consultations on the Provision of International Protection to All Who Need It, UN Doc. EG/47/SC/CRP.27, 30 May 1997 at Section II, Paras. 4-5 (called Standing Committee 1997).

${ }^{8}$ Standing Committee, Complementary Forms of Protection: Their Nature and Relationship to the Intermational Refugee Protection Regime, UN Doc. EG/50/CRP.18, 9 June 2000 (called Standing Committee 2000).

9 See Chairman's Summary, Global Consultations, Protection of Refugees in Situations of Mass Influx, 8-9 Mar. 2001. 
ambiguities in key terms allocating rights in the Convention. However, the refugees involved may be persons protected from expulsion not only by the Convention, but also by the newer human rights treaties. So the content problems also relate to a lack of interpretation of human rights treaties as these apply to persons protected from expulsion.

Throughout, this essay shows that authoritative interpretation of treaties is needed to make the promise of the rights based refuge a reality for refugees. Although UNHCR can supervise its application, ${ }^{10}$ only the ICJ can offer an authoritative global interpretation of the 1951 Convention together with the various newer human rights treaties. ${ }^{11}$ However, UN human rights treaty committees can offer authoritative interpretations of at least the many applications of human rights treaties to rights based refuge. Existing treaty bodies, for example the UN Human Rights Committee (HRG) acting under the CCPR, could provide a parallel line of protection drawing on CCPR rights available to everyone. The CGPR Article 26 right to non-discrimination is of particular signficance. It applies to all situations in which a right or benefit is allocated so that the HRC interpretation of CCPR Article 26 applies to rights offered by the 1951 Gonvention. The 1951 Convention permits distinctions among categories of refugees in their enjoyment of rights under the 1951 Convention. In these ways the HRC can reinforce aspects of the Convention. ${ }^{12}$ Although there is some potential for other authoritative international interpretation of rights based refuge related to the 1951 Convention in its new human rights context, a treaty committee with authority to interpret the 1951 Convention could make a useful contribution alongside the existing UN human rights treaty committees, facilitating joint or common interpretations of the various treaties relevant for refugee situations.

In concluding, this essay endorses a move from State discretion towards temporary protection that follows parallel human rights treaty obligations and obligations under customary law. ${ }^{13}$ The basis for a wider rights-based protection for refugees is already largely in place.

\section{Rights Based Refuge, Temporary and Complementary Protection}

\subsection{Refuge Versus Asylum}

There has been a confusion between asylum and rights based refuge. An international perspective on the right to asylum assigns it three

\footnotetext{
101951 Convention, Art. 35.

11 The context for interpretation is that of a dispute among State Parties which cannot be resolved by other means. 1951 Convention, Art. 38.

12 Clark with Grépeau (1999), above n. 5 at 393.

13 Lauterpacht and Bethlehem, above n. 1, at 149-163.
} 
elements: right of entry; protection from forced return; and rights while remaining. ${ }^{14}$ There is no global treaty right to asylum. The grant of asylum remains a discretionary act by a State. ${ }^{15} \mathrm{~A}$ world conference aimed at adopting a treaty on territorial asylum based on the UN Declaration on Territorial Asylum collapsed in $1977 .{ }^{16}$

The 1951 Convention, on the other hand, promises protection from forcible return and rights while present or staying. It does not promise a right of entry. A right to asylum comes from other human rights treaties because any right of entry presently comes from these treaties. ${ }^{17}$ Governments were evidently unwilling to grant a clear right of entry which would have completed a full right of asylum. The lack of a right of entry, that is, the lack of a right to arrive in a place of refuge, brings major problems which this essay will not explore. However, if the person can enter a State party to the 1951 Convention, Article 31 provides that an illegal means of arrival will not result in penalties. ${ }^{18}$ Article 33 refuge - non-refoulement is as far towards a right to asylum as governments went when they adopted the 1951 Convention. The Convention offers protection from return, rights while remaining, and an alternative to a right of entry - the overlooking of illegal entry. The combination of Article 33 with the other relevant articles of the Convention is a form of rights based refuge. It is rights based because it can be asserted by an individual against a State party even when it is inconvenient, but only through domestic tribunals.

Whether one can go beyond 'entry overlooked' to a right of admission depends on the impact of the human rights treaties, discussed below, and on the legal significance of the 'Conclusions' of the Executive Committee of the UNHCR (EXCOM). The Vienna Convention on the Law of Treaties is the standard for treaty interpretation. Article 31 requires using the ordinary meaning of the text in context of the whole treaty including its purpose. It also requires using the juridical context of subsequent agreements by States Parties relating to the interpretation of the treaty. ${ }^{19}$ Since the 1951 Convention text was adopted, certain States have reached some less formal agreements. In particular, Conclusion No 22 of

\footnotetext{
${ }^{14}$ For example, see C.L.C. Mubanga-Chipoya, Final Report, The Right of Everyone to Leave any Country, Including His Owm, and to Retum to His Country, UN Doc. E/C.4/Sub.2/1988/35, June 1988, 103-106.

${ }^{15}$ Goodwin Gill, above n. 2, at 172-174.

16 Ibid., at 175 and 181 .

17 General Comment 15 of the UN Human Rights Committee hints that non-discrimination and family rights may provide a right of entry. They would stem from single or combinations of Covenant on Civil and Political Rights Arts. 17, 23, 24 and 26. Convention on the Rights of the Child Arts. 9 and 10 complement such CCPR rights. Thus a spouse and child of an asylum seeker likely have a right of entry to the State once the asylum seeker has claimed refugee status from the authorities.

18 It is inappropriate to blame refugees for using the arrangements provided to seek and enjoy asylum - illegal arrival.

191969 Vienna Convention on the Law of Treaties, 1155 UNTS 331. See Lauterpacht and Bethlehem, above n. 1, at para. 40 .
} 
the Executive Committee of the UNHCR's program is about protecting asylum seekers in large scale influxes. ${ }^{20}$ Conclusion 22 requires the State where the refugees first seek refuge to always 'admit' refugees, at least on a temporary basis. The EXCOM is a distinct body of the UN and its Conclusions have interpretive value for the 1951 Convention. ${ }^{21}$ This interpretive value is reinforced when the Conclusion refers directly to an aspect of the 1951 Convention, as in the case of Conclusion No. 22. An EXCOM report with the Conclusions may be the object of one or more subsequent Resolutions of the General Assembly. In some judgements, the ICJ has considered resolutions of the General Assembly as persuasive. Authoritative interpretation would likely find that a large scale influx presenting to border officials at a land border where the State has jurisdiction must be admitted for Article 33 refuge. The issue of limits is discussed later, below.

\subsection{Non-refoulement - Article 33 Refuge}

The 1951 Convention can be viewed as consisting of three parts: (1) Article 33 refuge or non-refoulement; (2) rights and obligations while in fact present or remaining; and (3) a Convention refugee definition, Article 1. This essay considers Article 33 non-refoulement and related rights as expanded by human rights from other treaties States have often also ratified.

It is by now established that if a refugee can find a way to arrive within State territory, Article 33 of the Convention prohibits returning any 'refugee' in any manner whatsoever to a country where their life or freedom would be threatened. ${ }^{22}$ This 'non-refoulement' is not absolute. ${ }^{23}$ Its effect in the Convention text is to allow refuge which is temporary pending the adjudication of status of individuals or of groups who may be refugees. The person's refugee status is recognized by the State applying the Convention definition. The term 'refugee' used in the text of the 1951 Convention includes those claiming refugee status - asylum seekers. Persons without documents specified in domestic law, undocumented

${ }^{20}$ Conclusion No. 22 (XXXII), 1 981, Goodwin-Gill 1996, above n. 2, at 480-483.

21 Lauterpacht and Bethlehem, above n. 1, at paras. 28 and 29.

22 Art. 33 (1) No Contracting State shall expel or return 'refoule' a refugee in any manner whatsoever to the frontiers of territories where her life or freedom would be threatened on account of her race, religion, nationality, membership of a particular social group or political opinion. (2) The benefit of the present provision may not, however, be claimed by a refugee whom there are reasonable grounds for regarding as a danger to the security of the country in which she is, or who, having been convicted by a final judgement of a particularly serious crime, constitutes a danger to the community of that country.

${ }^{23}$ The references to crime, danger and national security in Arts. 33 and 32 link to concerns also present in exclusion clause $1(\mathrm{~F})$ which prevents persons who have committed war crimes, crimes against humanity and serious non political crimes from obtaining protection (here - refuge). Geoff Gilbert, 'Current Issues in the Application of the Exclusion Clauses', in Feller, Türk and Nicholson above, n. I, at 425 . 
persons seeking refuge, are not excluded from the term 'refugees' because the Convention provides that these 'refugees' be given administrative assistance and documentation. ${ }^{24} \mathrm{~A}$ person must be considered a Convention refugee at least until that person is found not to be a Convention refugee. ${ }^{25}$

Even without Conclusion No. 22, mass exoduses from civil conflict should benefit from Article 33 refuge if they arrive on State territory. Like any plausible asylum seeker, they qualify for protection at least until determined not to be Convention refugees. Populations fleeing civil conflicts often include numbers of Convention refugees so that there is a reasonable presumption that a person claiming to be a refugee may be found to be one. Thus EXCOM Conclusion No 22 confirms the application of the Convention Articles 33 and 31 for a large scale influx, at least on a temporary basis.

What about individual asylum seekers? EXCOM Conclusions making references to country of first arrival (No. 22) and to determining the country with responsibility (No. 15) introduce ambiguities, but do not remove the offer of refuge to individuals from civil conflicts. State practices allowing some persons from serious conflicts to remain with or without some alternative status are compatible with this interpretation. ${ }^{26}$ Thus, Article 33 refuge should protect refugees in massive exoduses from civil conflict as well as protecting some individual refugees who do not qualify for formal Convention refugee status. For this to become internationally consistent, States would need more international guidance on how to establish a person as qualifying for mandate status and when temporary refuge ends so that individual repatriation might be contemplated.

The correct interpretation of all these terms has become important because States have put in place measures for the management of migration and the implementation of the 1951 Convention. ${ }^{27}$ These measures could be viewed as forms of burden sharing or even burden passing, but they are based on the notion that a State can be designated as 'safe' for return in the full range of circumstances which individuals present.

Considering only the 1951 Convention, the possibility of finding another country should be interpreted so as to mean another country

\footnotetext{
24 See Convention Arts. 25 and 27.

25 The UNHGR has allowed that 'manifestly or fraudulent' claims to refugee status can be dealt with in an expeditious manner because they do not merit 'full evaluation at every level of the procedure', but the general principle remains. See Conclusion No. 30 (XXXIV), 1983, para. (d).

${ }^{26}$ For example Temporary Protected Status (US), B status (Netherlands), tolerated (Germany), resident status on humanitarian and compassionate grounds (Canada), or persons on a list of countries to which there is no deportation (Canada).

27 For example, Council Regulation (EG) No. 343/2003 of 18 Feb. 2003 establishing the criteria and mechanisms for determining the Member State responsible for examining an asylum application lodged in one of the Member States by a third country national, Official foumal of the EU, L050, 25 Feb. 2003, at $1-10$.
} 
which can be relied upon to formally apply all the relevant protections of the 1951 Convention to the person or persons. Otherwise, it would be contrary to the evident intent and purpose of the Convention regarding non-refoulement. Automatic return would also be contrary to the protection of fundamental UN treaty rights. According to the limited case law of the human rights treaty bodies, the State which exposes a person to a foreseeable real risk of the violation of a fundamental right by expulsion is itself held to have violated the person's right. Once an individual claims rights based refuge under obligations from the 1951 Convention, the person is lawfully present and the State should ensure the related rights in all the circumstances which the individual presents. ${ }^{28}$

In contrast, present asylum-seeker transfer agreements to supposedly safe third countries or home countries are based on the presumption that the State in question will honour fundamental human rights obligations in any circumstances presented by an individual. Any transfer of a person claiming rights based refuge from the jurisdiction of one State to the jurisdiction of another State requires measures to ensure protection of fundamental rights in the particular circumstances of the case. For the Americas, there has been some authoritative interpretation on related issues. Automatic return would not meet the due process concerns raised by the Inter-American Commission on Human Rights in its Report on Canada's refugee determination system, discussed further below. Elsewhere, authoritative interpretation of treaty obligations is needed to establish these views.

Non refoulement - Article 33 refuge - is both massively affirmed by States and at the same time honoured in the breach. Over the years UNHCR has welcomed the affirmation and has been critical of these breaches, but they continue. They include border turn backs when the person is on State territory and return of persons coming from States deemed 'safe'.

\subsection{Beyond the 1951 Gonvention to Rights Based Refuge}

The interpretation of the 1951 Convention has become more nuanced since the international human rights treaties came into force. Many States have ratified both the 1951 Convention and the CCPR. As noted above, the Vienna Convention on the Law of Treaties requires that the 1951 Convention be interpreted on the basis of the ordinary meaning of the text in the context of the whole treaty and using the juridical context of subsequent agreements. Subsequent agreement includes the texts of the other human rights treaties and the related jurisprudence. ${ }^{29}$ It is not widely

\footnotetext{
${ }^{28}$ Tom Clark with Francois Crépeau, 'Human Rights in Asylum Sharing and Other Human Transfer Agreements', 22 NQHR 217, (2004).

29 '... An international instrument has to be interpreted and applied within the framework of the entire legal system prevailing at the time of interpretation ..., Legal Consequences for State of the Continued Presence of South Africa in Namibia (South West Africa) Notwithstanding Security
} 
appreciated that non-discrimination under the Covenant challenges the 1951 Convention in the many areas where it assigns rights on the basis of whether a person is a 'refugee', a 'refugee lawfully in the territory' or a 'refugee lawfully staying'. ${ }^{30}$ Article 26 of the CCPR extends nondiscrimination beyond the GCPR to any right or benefit, thus including those of the 1951 Convention. The related doctrine of non-discrimination developed by treaty bodies in their jurisprudence applies when interpreting any distinctions. To avoid breaching the Covenant, the general doctrine requires that any distinction be established in law, for a legitimate purpose, necessary and proportionate. The HRC refers to a distinction being 'objective and reasonable' given the rights of the CCPR. ${ }^{31}$

It is clear that the human rights treaties have provided a broader non-refoulement protection than is established by Article 33 of the 1951 Convention. Article 3 of the Convention against Torture is particularly clear in protecting a person from return to face a serious probability of torture. ${ }^{32}$ The GCPR has been interpreted in case law by the HRC as protecting a non-citizen from forcible return when it is predictable that aspects of the right to life would be violated or when cruel treatment would result. ${ }^{33}$

With hindsight, it is more remarkable that the human rights treaty bodies did not make an earlier connection between non-refoulement and the protection of CCPR rights - including the special due process

Council Resolution 276 (1970), Advisory Opinion, ICJ Reports, 1971, at 16 para. 53; '... Treaties that affect human rights cannot be applied in such a manner as to constitute a denial of human rights as understood at the time of their application...', Gabcikovo-Nagymaros Project (Hungary/Slovakia), Judgment, ICJ Reports 1997, at 7 paras. $114 ;$ ' ... to determine the legal status of the American Declaration it is appropriate to look to the inter-American system of today in the light of the evolution it has undergone since the adoption of the Declaration, rather than to examine the normative value and significance which that instrument was believed to have had in 1948', 'Interpretation of the American Declaration of the Rights and Duties of Man within the Framework of Article 64 of the American Convention on Human Rights', Advisory Opinion OC10/89, Inter-American Court of Human Rights, 14 July 1989, at para. $37 ;$ '.. the Convention is a living instrument which ... must be interpreted in the light of present day conditions', Tyler v. U.K., Judgment, European Court of Human Rights, Series A, No. 26, 25 Apr. 1978, at Para. 31.

30 Clark with Grépeau (1999), above n. 5, at 393.

31 Tom Clark with Jan Niessen, Equality Rights and Non-Citizens in Europe and America: The Promise, the Practice and Some Remaining Issues, 14 NQHR 245, 1996, 251. See also Manfred Nowak, U.N. Covenant on Civil and Political Rights: CCPR Commentary, Kehl/Strasbourg/Arlington: N.P. Engel, 1993, 465-466, $473-474$.

${ }^{32}$ Mutombo v. Suritzerland, Communication No. 13/1993, Views 27 Apr. 1994, UN Doc. GAT/C/12/D/13/1993, Elmi v. Australia, Communication No. 120/1998, Views 17 Nov. 1998, UN Doc., Alan v. Sreitzerland, Communication No. 21/1995, Views 8 May 1996, UN Doc. GAT/C/ 16/D/21/1996, Ayas v. Switzerland, Communication No. 97/1997, Views 12 Nov. 1998, UN Doc. GAT/C/21/D/97/1997, Paez v.Sweden, Communication No. 39/1996, Views 28 Apr. 1997, UN Doc. GAT/G/18/D/39/1996. For analysis see Brian Gorlick, The Convention and the Committee Against Torture: A Complementary Protection Regime for Refugees, 11 IJRL 479 (1999).

${ }^{33} \mathcal{N g}$ v. Canada, Communication No. 469/1991, Views 7 Jan. 1994, UN Doc. GCPR/C/49/D/ 469/1991; Judge v. Canada, Communication No. 829/1998, Views 20 Oct. 2003, UN Doc. CGPR/ $\mathrm{C} / 78 / \mathrm{D} / 829 / 1998$. 
safeguard for non-citizens - CCPR Article 13. In the ordinary meaning of the words, CCPR rights to life and liberty are at issue whenever 1951 Convention non-refoulement is at issue. The coming into force of the CAT enabled some progress. The prevention of return to torture under Article 3 of the CAT has influenced the interpretation of CCPR protection from torture and cruel treatment or punishment under CCPR Article 7. This has an enormous potential impact on what happens at the border. Despite the slow development of human rights treaty case law, border practices and the use of burden sharing mechanisms for assigning responsibility for refugee status determination are being challenged. ${ }^{34}$ States must now protect any person under their jurisdiction from expulsion when there is as a foreseeable consequence a real risk of the violation of some fundamental or important rights or freedoms. ${ }^{35}$ But some big questions remain. The HRC has talked briefly about rights of entry for non-citizens in General Comment $15 .{ }^{36}$ Does a right of entry apply to a person on a border, under jurisdiction of a State official and facing an evident real risk of torture? This was part of the Macedonian experience facing Kosovar refugees in 1999. The HRC and the Committee against Torture could give an authoritative interpretation of CCPR and CAT on the matter.

The European Convention on Human Rights has been interpreted by the European Court of Human Rights as prohibiting the forced return of non-citizens when torture or inhuman or degrading treatment or punishment would result. ${ }^{37}$ Although the situation is usually distinct from that of an asylum seeker, international human rights law has also established limits to the expulsion of non-citizens when separation of the core family would result. ${ }^{38}$ The Court was more restrictive in recognizing family rights and children's rights in entry. ${ }^{39}$

34 Clark with Crépeau (2004), above n. 28, presents such a challenge.

35 The rights that have been at issue in expulsion or extradition are: the right to freedom of movement; the right to seek and obtain asylum; the right to life; the right to protection from torture and cruel, inhuman or degrading treatment or punishment; family rights and children's rights; and, the right to an effective remedy and/or access to courts. See Clark with Grépeau (2004), above n. 28, at 222-225. See also Tom Clark and Sharryn Aiken with Barbara Jackman and David Matas, Intermational Human Rights Law and Legal Remedies in Expulsion: Progress and Some Remaining problems with Special Reference to Canada, 15 NQHR 429, 435 (1997).

36 See above n. 17.

37 Soerïng v. U.K.,Judgment 19 Jan. 1989, Ser. A161(1989), Chahal v. U.K., Judgment 15 Nov. 1996, Reports of Judgments and Decisions 1996-V (1996); Hilal v. U.K., Judgment 6 Mar. 2001, Reports of Judgments and Decisions 2001-II, (2001).

38 Early case law prohibited expulsion of even a very serious criminal see Moustaquim v. Belgium, Judgment 18 Feb. 1991, Ser. A193 (1991). Some dissenting judgments anticipated review of criteria in Nasri v. France, Judgment 13 July 1995, Ser. A320-B (1995). The Court pulled back, allowing expulsion for very serious crime in Bouchelka v. France, Judgment 29 Jan. 1997, Reports of Judgments and Decisions 1997-I (1997). The Court continues to prohibit expulsion for quite serious crimes when there is reasonable residence established in Radovanovic v. Austria, Judgment 22 Apr. 2004. (1996).

9 See Gül v. Sievizerland, Judgment 19 Feb. 1996, Reports of judgments and Decisions I996-I 
The Inter-American Commission on Human Rights has interpreted the OAS Charter human rights obligations as they apply in refugee status determination in Canada, emphasising due process concerns at various stages. The Commission's interpretation would require access to the courts to litigate violations of fundamental rights and high due process standards for rights at issue in access and in expulsion situations. ${ }^{40}$ Gilbert reached a related conclusion with respect to high due process standards in aspects of 1951 Convention non-refoulement. ${ }^{41}$

A final impact of the human rights treaties is on the responsibility of the UNHCR for supervising State application of the Convention. The significance of UNHCR's advice is diminished by the fact that the 1951 Convention must now be applied in a context of parallel human rights treaty protections that the UNHCR lacks the authority to interpret.

To indicate that the 1951 Convention no longer stands alone, I have used the term 'rights based refuge' for the wider protection of 1951 Convention Article 33 refuge combined with related protection of the human rights found in other treaties. Rights based refuge has the potential to meet the need for additional protection, whether 'temporary protection' or 'complementary protection', which governments and the UNHCR have recognized. ${ }^{42}$ An authoritative interpretation, an Advisory Opinion from the Inter-American Court of Human Rights or the International Court of Justice would reinforce the decisions of the treaty bodies in influencing State practice and encouraging corresponding legislative change and national court decisions.

\section{Content Rights}

In addition to differences in accessing rights based refuge, the inconsistent granting of rights to those possessing this status is a further problem. ${ }^{43}$ What happens once the rights based refuge has been secured matters. Can these people work or get social assistance? Do they get essential medical care? Can a child go to school? When can a spouse or child join them? Human rights are not enjoyed as individual rights - they are enjoyed as a

\footnotetext{
40 'The American Declaration of Rights and Duties of Man provides in Article XVIII that every person has the right to resort to the courts to ensure respect for [...] legal rights, and to have access to a simple, brief procedure whereby the courts will protect him or her from acts of authority that ... violate any fundamental constitutional rights. The right of access is a necessary aspect of the right to resort to the courts set forth in Article XVIII. The right of access to judicial protection to ensure respect for a legal right requires available and effective recourse for the violation of a right protected under the Declaration or the Constitution of the country concerned.' (Emphasis added). Inter-American Commission on Human Rights, Report on the Situation of Human Rights of Asylum. Seekers Within the Canadian Refugee Status Determination System (2000), at para. 95. See also para. 98.

41 Gilbert, above n. 23, at 470-471.

42 Standing Committee 2000, above n. 8, at paras. 10-11 and 20-22.

43 See Standing Gommittee 1997, above n. 7, and James C. Hathaway and John A. Dent, Refugee Rights: Report on a Comparative Survey, Toronto: York Lanes Press, 1995.
} 
complete package necessary for human dignity, security of the person and a sense of well being. Rather like health, all the other human rights are affected when even one right is not enjoyed. More specifically, uncertain procedures and family separation give rise to worse symptoms of post traumatic stress disorder among asylum seekers. ${ }^{44}$ A State concerned about honouring human rights obligations should offer as much clarity about the rights relating to the condition of refuge as is possible for a situation which, unlike Convention refugee status itself, is intended to be temporary.

In EXCOM Conclusion No. 22, Protection of Asylum Seekers in Situations of Large Scale Influx, States agreed on how the Convention was to apply in these circumstances. Article 33 refuge includes 'fundamental civil rights internationally recognized' and 'all necessary assistance' with the 'basic necessities of life including food, shelter and basic sanitary and health facilities ...' However, beyond the mass influx the minimum content of refuge is less clear.

The 1951 Convention text aims to create an international status and to allocate rights for an internationally defined class of persons, refugees. Yet the content of those rights as provided by States varies enormously, indicating a need for authoritative interpretation. ${ }^{45}$ This is a problem for the implementation of all human rights treaties as much as a problem of implementing and interpreting the 1951 Convention.

The 1951 Convention designates certain rights for three main groups: refugees; refugees lawfully on the territory; and refugees lawfully staying. ${ }^{46}$ All these terms are open to a variety of interpretations. The term lawfully on the territory' must include legal arrivals such as students and visitors, yet even this is not always followed in State practice. ${ }^{47}$ The overall scheme of the 1951 Convention implies a hierarchy in access to rights from Convention refugees to those newly arrived pending some decision. The governments in the Standing Committee of the EXCOM agreed in similar fashion that over time 'complementary protection' should take on the content of 1951 Convention rights. ${ }^{48}$

As noted above, the Vienna Convention on the Law of Treaties calls for interpretation of the 1951 Convention in its current juridical context alongside other human rights treaties. The UN human rights treaties promise rights without discrimination to everyone on the territory. Yet this promise itself remains to be realized. ${ }^{49}$ The human rights treaty bodies

\footnotetext{
44 See for example the report submitted by the Inter-Church Committee for Refugees to the UN Human Rights Committee in 1990, and Brigit Lie, Nils J. Lavik and Petter Laake, Traumatic Events and Psychological Symptoms in a Non-clinical Refugee Population in Nonway, I4 JRS 276 (2001).

45 Hathaway and Dent, above n. 43.

46 Goodwin Gill, above n. 2 at 307.

47 Goodwin Gill, above n. 2 at $307-308$.

48 Standing Committee 2000 above n. 8 at para. 25(f).

49 Clark with Niessen, above n. 31 at $260-272$.
} 
have their own particular interest in content rights because rights-based refuge results in part from the application of the human rights treaties and not just the application of the 1951 Convention.

Yet the human rights system has added some of its own complications. While not binding, the 1988 UN Declaration on the Human Rights of Individuals who are not Nationals of the Country in Which They Live allowed non-citizens 'lawfully on the territory' the right to liberty of movement and freedom to choose their residence (Art. 5.3). Non-citizens 'lawfully residing' enjoy safe and healthy work conditions, the right to join trade unions, the right to health protection, medical care, social services, education. Distinguishing 'lawfully in the territory' from 'staying' is practically impossible in the range of real life situations presented by refugees and asylum seekers. It is unfortunate that this initiative failed to set out a clear package of minimum rights which apply to refugees and asylum seekers who, as a matter of fact, stay. As argued above, any division of noncitizens into groups to enjoy or not enjoy rights or benefits must be established in law, legitimate, necessary and proportionate in the range of particular circumstances which arise. The later text of the 1990 Migrant Worker Convention would allow those who are not documented to benefit from certain rights, among them: working conditions (Art. 25); social security (Art. 27); urgent medical care (Art. 28); education (Art. 30). ${ }^{50}$ However, to qualify, a person must have worked in the State so that any promise of rights from the Migrant Worker Convention applies only to refugees who can show they have worked.

\subsection{Content Rights for 'Refugees'}

The broadest category in the 1951 Convention is 'refugees'. Anyone who has refuge gets at least these rights from the Convention: administrative help (Art. 25); identity documentation (Art. 28); freedom of religion (Art. 4); within certain limitations, property (Art. 13); artistic rights (Art. 14), rationing (Art. 20); education (Art. 22); non-refoulement (Art. 33); no penalties for illegal entry (Art. 31); as well as: taxation, (Art. 29). These rights should also be enjoyed, without discrimination, by any non refugees in a substantially similar situation under human rights treaties. Nevertheless, these treaties are far less specific about the particular needs of those enjoying forms of rights based refuge and authoritative interpretation would be helpful.

\subsection{Content Rights for 'Refugees Lawfully on the Territory'}

According to the 1951 Convention in isolation, a refugee who is "lawfully in the territory' gets additional safeguards against expulsion under

\footnotetext{
50 The Convention on the Human Rights of All Migrant Workers and Members of Their Families, was adopted by the UN in 1990 and came into force 1 July 2003.
} 
Article 32 of the 1951 Convention. This article prevents any expulsion, with an exception on one of two grounds, national security and public order, and then only after due process and a delay. ${ }^{51}$ Such lawfully present refugees also receive additional rights to travel documents (Art. 28); self employment (Art. 18); freedom of movement (Art. 26). Articles 25-28 deserve notice because they are rare examples of clear-cut directions to contracting States about their obligations. All refugees without documents must be given help and identity papers. Refugees lawfully present are to get travel documents as well.

The term 'lawfully in the territory' will have a specific meaning in an international treaty. ${ }^{52}$ It must include at least what domestic law says so that someone with a visa or some other status should qualify. Yet it is not simply a matter of what domestic law says. The notion that an international perspective must be taken on the meaning of a human rights treaty applies widely, for example in determining what is 'criminal' ${ }^{53}$ A refugee recognized as qualifying for Convention refugee status in a State party would be lawfully present. It should also apply to a person with rightsbased refuge who also possesses some other document indicating the State acknowledges presence, such as a valid work authorization.

The term 'lawfully within the territory' exists in CCPR Articles 12 and 13. Thus the HRC can give guidance on its meaning, but it has been very cautious and there is little case law. However, it gave an 'objective-factual' clarification that a person litigating the CCPR Article 12 right to freedom of movement in Sweden was at least lawfully present for the purposes of litigating the right. ${ }^{54} \mathrm{~A}$ similar approach was taken by the European Court of Human Rights which ruled that an asylum seeker, who France argued was being held in an international zone, was in fact detained in a designated part of a hotel in France. ${ }^{55}$

51 Art. 32 (1) The Contracting States shall not expel a refugee lawfully in their territory save on grounds of national security or public order. (2) The expulsion of such a refugee shall be only in pursuance of a decision reached in accordance with due process of law. Except where compelling reasons of national security otherwise require, the refugee shall be allowed to submit evidence to clear himself, to appeal and be represented for the purpose before the competent authority or a person or persons specially designated by the competent authority. (3) The Contracting States shall allow such a refugee a reasonable period within which to seek legal admission into another country. The Contracting States reserve the right to apply during that period such internal measures as they may deem necessary.

${ }_{53}$ Clark with Crépeau (1999), above n. 5 at 398.

53 'If the Contracting States were able at their discretion, by classifying an offence as regulatory instead of criminal, to exclude the operation of the fundamental clauses of Articles 6 and 7, the application of these provisions would be subordinated to their sovereign will. A latitude thus far might lead to results incompatible with the object and purpose of the Convention' (emphasis added), European Court of Human Rights Öztürk v. Federal Republic of Germany, Judgment 21 Feb. 1983, Ser. A73 (1984), at 18.

54 Ismer Celepli v. Sreden, Communication No 456/1951, Views 2 Aug. 1994, UN Doc. CCPR/ C51/D/456/1991.

55 Amuur v. France, European Court of Human Rights, Judgement 25 June 1996, Reports of Judgments and Decisions 1996-III (1996). 
Using this very preliminary objective-factual approach, 'refugee lawfully in the territory' should include a person in a refugee status determination procedure who is at least lawfully present for the purpose of seeking refugee status. Similarly, the person who is being considered under some asylum sharing arrangement or other return arrangement related to the 1951 Convention, must be considered 'lawfully present' at least for the purposes of the application of that asylum sharing agreement or return agreement. It is questionable, however, whether one can infer all 1951 Convention rights are thus available on the basis of existing jurisprudence.

It is likely that the refugee lawfully on the territory for the application of an asylum sharing or return agreement is then also lawfully on the territory for the benefits of the enhanced procedural safeguards against expulsion which 1951 Convention Article 32 brings and for the benefit of the safeguard against expulsion in CCPR Article $13{ }^{56}$ An implication of this interpretation is that once the person has an important right at issue, the person is lawfully present until that matter has been addressed by the State and at least the related safeguards of the 1951 Convention plus human rights treaties have been applied. ${ }^{57}$ The Human Rights Committee could provide General Comments on such matters and on the application of Article 13 due process to asylum seekers in forms of expulsion, including asylum sharing agreements. This would be an authoritative interpretation of the CCPR.

On the objective-factual basis, lawfully in the territory also applies to a person with rights based refuge with respect to whom deportation has not been ordered or whose deportation has been suspended by the State. The person must be deemed accepted by the State as temporarily residing pending a change in circumstances which would allow deportation. Again, this should have the effect of requiring the enhanced procedural safeguards against expulsion of at least 1951 Convention Article 32 and CCPR Article 13, at least until refugee status is officially denied.

The Convention itself makes no distinction between dispersed individual refugees and massive exoduses of refugees. A government which has negotiated an arrangement for UNHCR to assist refugees on its

\footnotetext{
56 In contrast, a person who has been ordered deported and is nonetheless present, despite the reasonable efforts of the authorities to deport, is not lawfully present. A person whose authorized presence is no longer valid and whose continuing presence has not been made known to the authorities is not lawfully present.

57 The Human Rights Committee is unclear about 'lawfully on the territory' under GCPR Article 13 in General Comment 15. However, in Kindler v. Canada (Communication No. 470/1991, Views UN Doc. CGPR/C/48/D/470/1991) and again in Ahani v. Canada (Communication No. 1051/1992, Views 25 May 2004, UN Doc. GGPR/G/80/D/1051/2002 (2004)) Article 13 was applicable to persons being extradited for murder and on national security grounds, respectively. It appears that a person is 'lawfully in the territory' when a substantive treaty right is at issue. This view is supported at the Inter-American Commission on Human Rights in Foseph v. Canada Report No. 27/93, Case 11.092, Annual Report 1993 (1994). Joseph was underground at the time of her complaint. Her right to seek and obtain asylum was one of the rights at issue.
} 
territory must be presumed to have recognized that they are 'refugees lawfully in the territory' at least for the purpose of receiving the UNHCR assistance. Refugees in camps raise questions about rights to freedom of movement and liberty which will be explored in more detail below. In European, African and the Inter-American regional human rights treaties, refugees in camps benefit from protection against group expulsion..$^{88}$ However, exactly what qualifies as a 'group' requires authoritative interpretation. The safeguards of 1951 Convention Article 32 and CGPR Article 13 should apply to any individual case by case returns.

\subsection{Content Rights for 'Refugees Lawfully Staying'}

Considering the 1951 Convention alone, refugees 'lawfully staying' benefit from even more Convention rights: public relief like citizens (Art. 23); labour rights and social security like citizens (Art. 24); work, like the best for non-citizens (Art. 17); association and unionization like the best for non-citizens (Art. 15); access to liberal professions (Art. 19); housing (Art. 21). Like the term 'lawfully in the territory', 'lawfully staying' is not solely a matter of domestic law. It is a matter of international interpretation which likely follows the objective-factual approach. Also, the principle of non-discrimination can be applied to the restriction of several of these rights and benefits to such a particular social group.

In the objective-factual and non-discrimination lens, it is difficult to see a basis to automatically distinguish all persons in this group from all persons in a group lawfully on the territory. 'Staying' implies that these are refugees with a more secure basis for a finite period of residence. Evidently, these rights would apply to those with the status of Convention refugees. They should apply to all rights-based refuge 'refugees', including Mandate refugees who are as a matter of objective fact 'staying'. A person whose continued presence is known to the authorities and tolerated must be viewed as lawfully staying even if 'staying' amounts to only a few days. The Migrant Worker Convention, would allow irregular migrants who qualified as migrant workers and were 'staying' on an objective-factual basis to qualify for a majority of rights.

With some limitations on the right to work, the rights to work, education, health and some family rights apply to everyone under State jurisdiction allowed to remain. ${ }^{59}$ Some ambiguities which remained in the earlier study ${ }^{60}$ around (1) equal treatment before the courts for similar rights, (2) fair trial and (3) due process in expulsion by fair trial or by CCPR Article 13 have been further clarified. In the case of Ahani the HRC found that refugees being expelled on grounds of national security must receive equal

\footnotetext{
58 The collective expulsion of aliens is prohibited in regional human rights instruments; European Convention, Protocol No. 4 Art. 4, American Convention, Art. 22.9, African Charter Art. 12.5.

59 Clark with Niessen, above n. 31 at 270-273.

60 Clark with Niessen, above n. 31 at 266-269.
} 
benefit from GCPR Article 13. The Inter-American Commission on Human Rights interpreted OAS Charter obligations as including access to the courts to litigate rights and an appeal on the merits for a refused asylum seeker. ${ }^{61}$ Although this was a specific report on Canadian refugee status procedures, the interpretation of OAS Charter rights is applicable in the Americas.

The rights in temporary protection and complementary protection, which States were willing to offer on a discretionary basis, were intended by them to move to 1951 Convention rights as time progressed. This analysis suggests that many of the 1951 Convention rights may be available but as a consequence of the parallel protection from human rights treaties. However, there are some special circumstances which require greater care - emergencies and liberty.

\subsection{Towards a Core Content for Rights Based Refuge}

Despite some clear cut clarifications ${ }^{62}$ many ambiguities about content rights remain. True, human rights treaties like the GCPR have a built-in mechanism to provide clarification - the treaty bodies. Yet so far, the HRC has been cautious in finding State violations against asylum seeker non-citizens in its case law. There is little directly relevant case law on discrimination.

There is ample evidence that governments have not acknowledged all these rights for individual dispersed refugees and that access to even the 1951 Convention package of rights is mixed. ${ }^{63}$ It would be helpful for the treaty committees and UNHCR to offer some General Comment which clarified the content of rights based refuge much as the Sphere Project has developed minimum standards for meeting social and economic rights in a humanitarian emergencies. ${ }^{64}$ Also, on a practical note, States find it easiest to administer packages of rights by a simple label or status. In this regard, the use by States of a general temporary resident status for the various circumstances which arise would be a helpful basis for a package of minimum rights. ${ }^{65}$

61 Inter-American Commission on Human Rights (2000), above n. 40 at paras. 95-96, 104, 108.

62 A clear cut example is 1951 Convention Art. 16.2. It grants access to legal assistance for access to the courts only to 'refugees habitually present'. 'There is little doubt that this would be discrimination under the CGPR. Under the OAS Charter human rights there is no doubt. Legal assistance is recognized as an important component of the right to fair trial for everyone and the application to asylum seekers has been confirmed in jurisprudence. Thus the right is granted by the GGPR or OAS Charter system rather than the 1951 Convention.

63 Hathaway and Dent above n. 43.

64 The Sphere Project was launched in 1997 by a group of humanitarian NGOs and the Red Cross and Red Crescent movement. The project has developed several tools, the key one being a Handbook. The Sphere Humanitarian Charter and Minimum Standards in Disaster Response sets out for the first time what people affected by disasters have a right to expect from humanitarian assistance. See the web site at http://www.sphereproject.org/.

${ }^{65}$ It is yet to be seen whether this potential will be realized for 'temporary resident' status established by the [Canadian] Immigration and Refugee Protection Act, 2002. 
Minimum standards were suggested for a 'large scale influx' in EXCOM Conclusion No. 22, introduced above. This has considerable persuasive interpretive power - but for the intended context. Minimum standards for individual asylum seekers and the use of a status for them were suggested by the Standing Committee for complementary protection. ${ }^{66}$ These are largely established rights under human rights treaties: ${ }^{67}$

Standing Committee view on Civil and Political Rights ${ }^{68}$

- protection from refoulement and expulsion (see CGPR Arts. 6, 7, 12, 13, 17, 23, 24; CAT Art. 3)

- non discrimination - (see GGPR Art. 26)

- never to be subjected to torture or cruel inhuman or degrading treatment or punishment (see CGPR 7, CAT)

- freedom of movement without limits other than those necessary for public health or public order (see CCPR Arts. 9, 12)

- access to courts and administrative authorities (see CCPR Arts. 14, 26)

Standing Committee views on Social and Economic Rights ${ }^{69}$

- adequate housing

- assistance or employment

- health care as needed

- primary and secondary education.

Clark and Niessen identified some important Social and Economic Rights: ${ }^{70}$

- work (with some limits) or self-employment

- essential health care

- primary and secondary education

- family rights.

For a refugee to fully enjoy the rights promised requires a State to apply together several human rights treaties as well as the 1951 Convention. Some authoritative international interpretation of access to rights, and hence a State's treaty obligations, would be helpful. Yet at present there are only individual treaty bodies each with responsibilities towards a particular treaty. In theory, the treaty bodies might collaborate to produce joint General Comments on topics relating to asylum seekers, but, in practice, that would be expecting too much from already overworked members.

66 Standing Committee 2000, above n. 8 at paras. 14-17.

67 Clark with Grépeau (1999), above n. 5 at 409-410, and as discussed above.

68 Standing Committee 2000, above n. 8 at para. 16. The bracket references are mine, but see para. 15 which refers to the Bill of Rights and regional human rights instruments.

69 Standing Committee (2000), above n. 8 at para. 17.

70 Clark with Niessen, above n. 31 at 270-273. 


\section{Limits and Emergencies and Rights Based Refuge}

The 1951 Convention is not specific about what might be done in emergencies and about general limits on rights. According to the text itself, the right to refuge itself - protected by Articles 33, 32, 31 - may be limited when national security, public order or serious criminality is at issue in relation to a particular refugee. These terms are not defined. Article 9 allows for 'provisional measures' in time of war or other grave and exceptional circumstances 'which it [the State] considers essential to national security pending' status determination and beyond. However, in the ordinary meaning of the text, this is intended for a particular individual refugee and is not intended to be generally applied to a population and, therefore, cannot be considered a derogation clause. EXCOM Conclusion No. 22, introduced above, establishes minimum standards for a large scale influx - often related to an emergency. In the Macedonian situation facing Kosovar refugees, the issue of a right of entry to safeguard life or to prevent torture could be addressed by authoritative international interpretation of human rights treaties. The related issue of whether one might claim rights based refuge if one is under the jurisdiction of a State official also requires interpretation.

The non-discrimination principle of the CCPR would be met with more certainty by 'measures' which apply on the basis of objective criteria and which do not apply on the basis of nationality or status of the person. Distinctions between refugees as a social group and others should be avoided. One of the few positive features about the wave of national legislation to combat terrorism following the events of 11 September 2001 is that such legislation generally does not distinguish refugees from non-citizens or citizens. Nonetheless, while derogation from discrimination on enumerated grounds is always prohibited, derogation from the more nuanced aspects of CCPR Article 26 non-discrimination is possible subject to the conditions set by CCPR Article 4 .

Articles 32 and 33.2 provide a limited form of derogation within the 1951 Convention permitting expulsion or return on grounds of national security and public order. However, the CCPR provisions for the suspension of rights, in Article 4, require a higher threshold for derogating from CCPR rights involved refuge. ${ }^{71}$ This can have the effect of raising the threshold for expelling a refugee in an emergency. Yet there are situations in which even this high threshold might be met.

\footnotetext{
71 In time of public emergency which threatens the life of the nation and the existence of which is officially proclaimed, the States Parties ... may take measures derogating form their obligations ... to the extent strictly required by the exigencies of the situation, provided that such measures are not inconsistent with their obligations under international law and do not involve discrimination solely on grounds of race, colour, sex, language, religion or social origin.' CCPR, Art. 4.
} 
The situation of applicants for refugee status changes once the persons are in fact on State territory. It is quite possible that the situation which actually unfolded in Macedonia in 1999 might permit derogation under CCPR Article 4. Macedonia is a country with a small population of roughly 78 per cent Macedonians and 22 per cent Albanian Muslims. There was risk of civil conflict with sections of the Albanian community. In addition, the location of the newly arrived refugees threatened to contaminate springs of water supplying the capital city of Skopje where a significant fraction of the population resides. Thus, not one, but two of the typical enumerated bases for limiting rights were involved. Arguably, the CGPR Article 4 test might have been met. The significance of EXCOM Conclusion No. 22 discussed above is uncertain. It calls on States to at least admit refugees temporarily and it is clear from the context that the situation of massive influx could amount to an emergency.

The situation is more complex because, as Morton Kjaerum noted, ${ }^{72}$ other rights are at issue. Protection from torture or from cruel, inhuman or degrading treatment or punishment can never be derogated. Macedonia might have justified returning refugees on the ground of national security under 1951 Convention Article 32 even when Article 33.2 is interpreted using the high threshold from CCPR Article 4. Yet returning refugees in the face of a foreseeable real risk of death or torture or cruel treatment would have violated non-derogable CGPR and CAT rights.

Macedonia was in the impossible situation of having an obligation it could not meet without help. Responsibility sharing and burden sharing allowed outside assistance for the refugee population and it allowed a number of refugees to be relocated in other countries. Convention Article 31.2 implies the possibility of the refugees going to another country - but does not provide any means of implementation. The problem here is that Macedonia had to 'ensure' (CCPR Art. 2.1) protection from torture and cruel treatment to everyone on its territory. It could only do this with assistance from outside. Macedonia has also to 'take the necessary legislative or other measures' (Art. 2.2) to ensure that protection. It is pure pragmatism that if rights based refuge is to be viable in large scale emergencies, some form of guarantee for the burden and responsibility sharing must be in place. ${ }^{73}$ It is a conclusion reached by Hathaway and Neve. ${ }^{74}$ The need for formalized burden-sharing was clear in 1981 in

\footnotetext{
72 Michael Barutciski and Astri Suhrke, 'Lessons from the Kosovo Refugee Crisis: Innovations in Protection and Burden-sharing', 14 JRS 95, 2001. See also 'Responses' by Morten Kjaerum 14 JRS I 16 and by Terje Einarsen 14 JRS 19, and 'Rejoinders' 127, 128.

73 Barutciski and Suhrke, above, n. 60.

74 James G. Hathaway and R. Alexander Neve, Making Intemational Refugee Law Relevant Again: A Proposal for Collectivized and Solution oriented Protection, 10 Harvard Human Rights Journal 115 at 118 (1997).
} 
Conclusion No 22, but no mechanism has been developed over the intervening decades.

\subsection{Limits on Liberty and Freedom of Movement}

The 1951 Convention does not contemplate detention as such, but in 1995 UNHCR issued Guidelines on the Detention of Asylum Seekers. The Standing Committee subsequently asked that they be updated to include human rights law. ${ }^{75}$ The international legal status of the UNHCR Guidelines is uncertain. The vague 'precautions' of 1951 Convention Article 9 do not specifically include or exclude restrictions on movement but they are limited to times of war or related exceptional circumstances, are to be individually applied and must causally relate to national security. Article 31 the 1951 Convention contemplates restrictions on movement which apply only to refugees unlawfully in the territory by illegal entry or presence. Restrictions are to be 'necessary'. They last until status is regularized or until the refugee obtains admission in another country. The earlier discussion about the interpretation of 'lawfully in the territory' raises questions about the application of general restrictions to movement. The Article 9 term 'status' must be interpreted internationally so it need not be limited to a formal status which a State assigns under domestic law, although that would also qualify. From the international perspective of UNHCR, Convention refugees have the status before a State recognizes it. So any interpretation of restrictions of movement should not depend on lack of formal domestic status. Also, the ordinary meaning of the Convention article puts the restrictions in the form of conditions for release such as those a State might apply when granting an individual bail.

CCPR Article 12 grants freedom of movement for all those lawfully in the territory, with limits. It is distinct from liberty - implying a wider mobility within the State and beyond. This essay has suggested that applicants for refugee status qualify as 'lawfully in the territory' for the purpose of refugee status determination. If lawfully on the territory for any one reason, they should enjoy freedom of movement. Any limits to GCPR freedom must be established in law and necessary to protect national security, public order, public health or morals, or the rights and freedoms of others. The limits must be compatible with the CCPR. For example, measures which resulted in refugees being detained more as a group than other groups, such as citizens, could be discriminatory unless there was a reasonable objective justification. Limits are exceptions and may not become the rule. ${ }^{76}$ Thus, the general restriction of movement of individual

${ }^{75}$ Standing Committee, Progress Report on Informal Consultations on the Provision of Intermational Protection to all Who Need It, UN Doc. EG/48/SG/CRP.32, 1998, Section III, Para. 5.

76 Manfred Nowak, UN Convention on Civil and Political Rights: CCPR Commentary, Kehl/Strasbourg/ Arlington: N.P Engel, 1993, 206-2217. 
dispersed asylum seekers is prohibited. Similarly, the State which agrees to allow UNHCR to assist a mass influx population has acknowledged that the refugees are lawfully present - at least for the purpose of being assisted by UNHCR. A status is imputed and any restriction on the freedom of movement must be justified under CCPR Article 12 unless this is derogated in a national emergency.

Some State practice is in part compatible with the above views. For example, asylum seekers are detained in the USA until the domestic law allows the person to begin the refugee status determination process. Then the person is released as if the person is deemed lawfully present for the purpose of status determination. However, this situation in the USA is complicated by the related right to liberty which will be briefly explored.

CCPR Article 9 grants liberty, but allows restrictions. Deprivation of liberty is presumed to involve arrest and detention. But there are procedural safeguards on these restrictions. Deprivation of liberty cannot be arbitrary. The basis must be in law. The person must be told the reasons, is entitled to go to a court to seek release, and must be compensated for unlawful arrest or detention. ${ }^{77}$ The European Convention on Human Rights explicitly allows a non-citizen to be detained in order to ensure expulsion. ${ }^{78}$ However, detention for the purpose of deportation ceases to be lawful if the deportation cannot be carried out or is indefinite. This is an area in which the treaty body can give an authoritative interpretation of the State's obligations with respect to liberty as they relate to a variety of situations facing asylum seekers and refugees.

\section{Interpretation and Supervision of the Convention}

UN human rights treaty bodies can already consider aspects of the 1951 Convention in terms of parallel rights in the relevant human rights treaty. ${ }^{79}$ However, time and again, this essay has shown that authoritative interpretation of the Convention in the context of other human rights treaties would provide a basis for a clearer and more consistent rights based refuge. The ICJ may resolve disputes between States as provided in the 1951 Convention and in doing so it may interpret the Convention and could resolve ambiguities. According to its Charter, the UN has standing before the ICJ ${ }^{80}$ and the ICJ is evidently competent to interpret the 1951 Convention in advisory opinions, if asked. However, a treaty committee specifically for the 1951 Convention would usefully insulate the ICJ from

77 Nowak, above n. 75 at $174-182$.

78 European Convention on Human Rights and Fundamental Freedoms, Art. 5.1.f.

79 Clark with Grépeau (1999), above n. 5 at 109.

80 The UN Gharter does not specify which organs of the UN have standing before the ICJ. Presumably some preliminary advisory opinion from the ICJ would have to be requested to resolve the technical matter of which UN organ could have standing in what circumstances. 
what might otherwise be an overwhelming number of advisory opinions. It could also serve to stimulate or enable other jurisprudence relating to refugee situations.

The later UN human rights treaties establish treaty bodies which are to receive reports, may receive complaints from individuals and make public their comments and views. To date, the supervision of the 1951 Convention has been largely discreet oversight by UNHCR with some UNHCR positions on issues and some submissions to assist States develop refugee related legislation. It would be helpful to have a more consistent application of the same Convention by the many States Parties and to have a more consistent package of rights for 'refugees' enjoying rights based refuge.

UNHCR invited an expert paper from Walter Kalin about supervising the 1951 Convention for its Global Consultations during $2001 .^{81}$ Kalin offered an exposition of the various treaty monitoring or supervisory mechanisms including the work of the human rights treaty committees. He weighed the value of UNHCR activity. UNHCR has access to statistics. Widespread State practice allows UNHCR a presence on State territory and the right to observe refugee related proceedings. He concluded with a proposal for enhanced supervision by a more formal component or group within the existing Standing Committee and EXCOM procedures. That may well be helpful. However, Kalin underestimated the importance for refugees and agencies which serve them of a form of monitoring which offers transparency and published facts. He fails to recognize the significance of authoritative interpretation which no ad hoc group can bring but which the human rights treaty bodies can provide. Surprisingly, he does not deal with the problem raised for supervision by the UNHCR and its EXCOM of the overlapping rights and obligations from the human rights treaties. The UNHCR cannot supervise a combination of 1951 Convention rights and other human rights. Equally, of course, other treaty bodies cannot monitor the 1951 Convention over which they have no remit. Others have reflected more sharply on the needs and possibilities for enhanced supervision by a body with the powers of the human rights treaty bodies. The importance of a full range of key functions like fact-finding and individual case law has been raised. The difference between discreet silence and public accountability is emotional and psychological as well as rational for refugees and for agencies working with them. Justice demands that a person who has been wronged has access to an authoritative body with power to confirm and publish the facts, pronounce on whether a right has been violated or not, and to provide redress. The same should be true if the person is a refugee.

81 Walter Kälin, 'Supervising the 1951 Gonvention Relating to the Status of Refugees: Article 35 and Beyond', in Feller, 'Türk and Nicholson above, n. 1, at 613-666. 
The human rights treaty bodies are not without problems. In a recent article, Saul Takahashi gives a good account of some pros and cons of the typical UN treaty body as compared with the UNHCR for monitoring the 1951 Convention. ${ }^{82}$ Yet he also misses the point raised several times in this essay. Authoritative interpretation is important. Judicial interpretation informs the national legislator and the national courts in their own language. It empowers NGOs for advocacy. UNHCR and the treaty committees play different but complementary roles. There should be no question of either/or. It is rather a question of both the UNHCR and a treaty committee. UNHCR promotes the implementation of the 1951 Convention as one half of its Statute mandate to protect refugees. It does so in an energetic and effective manner. Its role is rather like that of an ombudsman within a State. UHNCR is principled, but pragmatic. It gets something to happen. Yet its protection function must be reconciled with its other Statute mandate - to find solutions to the problem of refugees with governments. And the UNHCR must supervise the application of a Convention whose application depends on other human rights treaties over which UNHCR enjoys no similar authority. Equally, of course, human rights treaty bodies can only deal with matters in their own treaties taking into account the current juridical context in the wider international human rights law.

The fragility and lack of funding of the UN human rights treaty committees are widely know. Yet their positive aspects become clear to any NGO which works with them. The treaty committees can function in a quasi judicial or court-like manner when they issue jurisprudence. This gives a unique authoritative international interpretation of a treaty. In their second function of examining a State on its periodic reports, they draw on NGO and other public insights. In the examination process, they raise both issues and pertinent specific structural legal problems about the State. The entire exchange with a State is public. This is true when the exchange is the examination of a report and when it is an exchange of correspondence surrounding an individual complaint about an alleged violation of a treaty right. There is a public record, public criticism and suggestions. It is precisely this kind of openness about what is going on and this kind of authoritative interpretation which is lacking for the 1951 Convention. At the same time, the discreet diplomatic work of UNHCR is invaluable.

\section{Conclusion}

Non-refoulement - Article 33 refuge - is the central plank of 1951 Convention protection. The 1951 Convention refugee definition and its

\footnotetext{
${ }^{82}$ Saul Takahashi, Recourse to Human Rights Treaty Bodies for Monitoring of the Refugee Convention, 20 NOHR 53 (2002).
} 
application may affect some 1 million refugees each year. But Article 33 refuge impacts all the 10-15 million persons of concern to the UNHCR. The impact of the human rights treaties calls for re-examination. They question earlier interpretations. It is now recognized that non-refoulement has been reinforced by refuge from other human rights treaties, like the Convention against Torture. Nevertheless, their full impact has not been grasped. The 1951 Convention is still discussed largely in isolation from other human rights treaties. A notion of 'rights based refuge' better captures this new reality.

The central issue of the entry into States of asylum seekers in mass influxes can be addressed in part through the rights to life and liberty and protection from torture at issue by human rights treaty bodies.

The Standing Committee of the EXCOM of the UNHCR indicated a general willingness of the participating governments to accept temporary protection for mass exoduses and complementary protection with content rights, but subject to State discretion. When interpreted with human rights treaties, rights based refuge accords much of temporary protection and complementary protection as of right. The question of how to claim the right remains. One way of pressing beyond State discretion is to seek authoritative interpretations of these treaties as they apply to refugees.

The content rights of the rights based refuge is unclear beyond a minimal list in the 1951 Convention. In principle, the human rights treaties promise rights like health or education or access to courts without discrimination. So far, they have delivered little content to refugees in practice. Clarity about the content of rights relating to this refuge, about limits and emergencies and about due process rights is needed.

The UN treaty committees could, now, decide to monitor the enjoyment by refugees and asylum seekers of their rights and could, thus, in effect, monitor many aspects of the implementation of the 1951 Convention all as part of their examinations of State periodic reports. ${ }^{83}$ Yet the treaty bodies are restricted to interpretations of their respective treaties. Ultimately, only the ICJ can offer an authoritative international interpretation of the 1951 Convention as it applies together with the various newer human rights treaties. A treaty committee for the 1951 Convention, mandated to work alongside the other UN human rights treaty committees, could make a useful contribution at facilitating joint or common interpretations relevant for refugee situations. Such authoritative interpretation would empower the protection promoting diplomacy of the UNHCR.

The discretionary response which governments are so far willing to offer in response to the need for temporary protection and complementary protection is not enough in today's world. Humanitarian aid coupled

${ }^{83}$ Clark with Crépeau (1999), above n. 5 at 409-410. 
with lack of control of global development are creating anger and frustration in poorer regions of the world. As the world stumbles towards democracy and participation in domestic governments, aid and discretion must give way to a sense of justice and rule of law at the international level. A rights based approach with binding commitments may be not only desirable in principle, but also a necessary way of sustaining cooperation in the global community. 